\title{
A Bioenergetics Based Comparison of Growth Conversion Efficiency of Atlantic Cod on Georges Bank and in the Gulf of Maine
}

\author{
Ivan Mateo \\ Dept. of Fisheries, Animal and Veterinary Science, \\ University of Rhode Island, Kingston, RI 02881 USA. \\ Email: imateo32@cox.net
}

\begin{abstract}
Mateo, I. 2007. A bioenergetics based comparison of growth conversion efficiency of Atlantic cod on Georges Bank and in the Gulf of Maine. J. Northw. Atl. Fish. Sci., 38: 23-35. doi:10.2960/J.v38. m590
\end{abstract}

\begin{abstract}
Several authors state that foraging conditions and food web dynamics may be contributing to declines in Atlantic cod stocks. Therefore, it is essential to take a food web perspective to understand the complicated array of potential interactions affecting marine communities. The widely used Wisconsin Bioenergetics Model uses an energy-balance approach calculated on a daily time step and can be used to evaluate the effect of changes in prey resources on growth or food consumption. Bioenergetics models have been made for many important fishes within the Great Lakes. However, few have been developed for US Northeastern Continental Shelf fish species. Growth performance of Georges Bank and Gulf of Maine Atlantic cod during 2004 was examined using a bioenergetics model and available data on gut contents and growth of different ages. Growth efficiency, calculated from daily growth and consumption rates, was used as a measure of growth performance. Overall growth performance for Atlantic cod was significantly lower at Georges Bank than in Gulf of Maine. Monthly individual consumption demand and specific growth rates for Atlantic cod calculated from the bioenergetic model were significantly higher on Georges Bank than in the Gulf of Maine. Increasing water temperatures approached the upper limits of thermal tolerances for cod in Georges Bank, possibly leading to decreasing growth efficiencies. Growth efficiency of cod in the Gulf of Maine was less variable than on Georges Bank due to the more homogenous temperatures and energetic content of diets found in the former location.
\end{abstract}

Key words: bioenergetics, cod, Georges Bank, growth efficiency, Gulf of Maine.

\section{Introduction}

The Atlantic cod, Gadus morhua, is a demersal gadoid species distributed in the Northwest Atlantic from Greenland to North Carolina. In USA Atlantic waters, three major groups of cod have generally been recognized: Georges Bank, Gulf of Maine, and Southern New England-Middle Atlantic (Serchuk et al., 1994). Tagging studies, spawning time data, and growth rate analyses indicate that minimal interchange occurs between the Gulf of Maine and Georges Bank groups, but that extensive mixing prevails between cod populations on Georges Bank and in the Southern New England-Middle Atlantic region (Serchuk et al., 1994). The northwest Atlantic cod has been regarded as heavily overfished throughout its range, resulting in a crash in the fishery in the United States and Canada during the early 1990s (NEFSC, MS 2005). Size, age, and maturity have declined in recent de- cades. Fish age-classs $2-5$ comprise the majority of the catch, even though this species can live for over 20 years (Serchuk et al., 1994). Currently, scientific and management efforts have slowed the decline in cod abundance, although numbers continue to be low.

Several authors state that foraging conditions (including prey resources and water temperature) and food web dynamics may be contributing to declines in Atlantic cod stocks (Rose and Legget, 1989; Palsson, 1994; Worms and Myers, 2003; Chou et al., 2004; Frank et al., 2005). When food resources are limited, high densities and dietary overlaps among juvenile gadid species, and with other ground fish species, may also result in intraand inter-specific competition that would negatively affect growth rates and overall cod size (Rose and Leggett, 1989; Palsson, 1994). In addition, seasonal shifts in prey resources and water temperature may affect the potential 
growth rates of juvenile cod (Rose and Leggett, 1989). Poor quality feeding areas, which may vary over different time scales, may result in increased susceptibility to predation due to poorer condition and smaller sizes of fish (Rose and Legget, 1989).

Therefore, it is essential to take a food web perspective to understand the complicated array of potential processes and interactions affecting aquatic communities (Brandt and Hartman, 1993). Determining the strength of interactions and identifying which processes regulate populations will provide insight into the underlying mechanisms and conditions that mediate them (Brandt and Hartman, 1993). Bioenergetically-based food web models, used in conjunction with directed field sampling, provide an effective method for quantifying trophic interactions in a temporal, spatial, and ontogenetic framework (Hansen et al., 1993). The widely used Wisconsin Bioenergetics Model (Hanson et al., MS 1997) uses an energy-balance approach calculated on a daily time step, which allows fine grained analysis of estimation of predator trophic demand and the relationship of demand to prey supply over various time scales (Ney, 1993).

This sensitivity is particularly appropriate for dynamic conditions, such as those experienced by juvenile and adult cod, where environmental factors (e.g., water temperature, salinity), diet, and sizes are rapidly changing. The Wisconsin Bioenergetics Model has been used successfully to identify carrying capacity of systems, seasonal bottlenecks in food supply, and impacts of predation primarily in freshwater systems (Stewart and Ibarra, 1991). The model has also been used to estimate temporal consumption demand and growth in estuarine and marine waters (Brandt and Hartman, 1993). Other applications of the model include estimating mortality due to predation, and evaluating growth performance as influenced by changes in water temperature, prey quality and/or availability, and consumer density (Hewett, 1989; Hansen et al., 1993).

This study provided estimates of the growth performance of juvenile and adult Atlantic cod by applying a bioenergetics model to in situ temperature, fish growth and fish gut content data that were available for 2004 . Growth efficiency was used as a measure of growth performance. The relevant question of the study was: Does growth performance of juvenile and adult cod change across regions in the US Northeastern Atlantic Continental Shelf (Georges Bank, and Gulf of Maine)? The null hypotheses were:

1) There are no differences in the estimated growth and modeled consumption demand for Atlantic cod be- tween Georges Bank and Gulf of Maine, and

2) There are no differences in growth efficiency for Atlantic cod between Georges Bank and Gulf of Maine.

\section{Methods}

Consumption by Atlantic cod was modeled with the Wisconsin Bioenergetics Model (Hanson et al., MS 1997). This model uses an energy-balance approach in which total energy consumption $(C)$ over a particular time frame equals the sum of growth $(G$, positive or negative), metabolic costs $(M)$, and waste losses $(W)$ : $C=G+M+W$, with $G=G_{s}+G_{P}, M=R+S D A$, and $W=F+E$, where: $G_{S}=$ somatic growth, and $G_{P}=$ gonad production, $R=$ respiration, $S D A=$ specific dynamic action, $F=$ egestion, and $E=$ excretion. Growth can be calculated as changes in biomass (weight energy, carbon or nitrogen during an interval of measurements and includes somatic (protein and lipid) growth and the development of the gonads. For the purpose of a basic bioenergetic model budget, protein synthesis and lipid storage are usually considered together as somatic growth. Typically the model, which operates on a daily time step, is used to estimate consumption rates by individuals of a species at a given life history stage. The primary model inputs are thermal experience (temperature experienced by the predator), diet, prey and predator energy densities, and growth. The Hansson et al. (1996) cod model's default physiological parameters specific to cod were used (Table 1).

\section{Model Development}

Predator consumption rates are modeled based on the assumption that an individual fish cannot consume more than its stomach can contain, digest, and pass. The equation for specific consumption rate $(C)$ is:

$$
C=C_{\max } P f_{c}(T)
$$

where $C_{\max }$ is maximum daily consumption at the species' optimal temperature, and is an allometric power function $\left(C_{A} W^{C_{B}}\right)$ of the weight of the fish, where $C_{A}$ is the intercept of the mass dependence function for a 1 gram fish at $0^{\circ} \mathrm{C}$, and $C_{B}$ is the mass dependence coefficient (Hanson et al., MS 1997). $P$ (referred to as the $P$ value) is a proportion of maximum ration whose value can be manipulated so predicted growth curves closely match observed growth curves of the species in question, limiting potential for estimation error (Bartell et al., 1986). The term $f_{c}(T)$ is a temperature-dependent proportional scalar of consumption rate and requires knowledge of optimum and maximum feeding temperatures of the species. 
TABLE 1. Symbols and parameters values used to implement the energetic model for Gulf of Maine and Georges Bank cod taken from Hansson et al. (1996).

\begin{tabular}{|c|c|c|}
\hline Symbol & Parameter description & Parameter Value \\
\hline \multicolumn{3}{|c|}{ Consumption } \\
\hline$C_{A}$ & Intercept of the allometric mass function $(\mathrm{g} / \mathrm{g} / \mathrm{d})$. & 0.099 \\
\hline$C_{B}$ & Slope of the allometric mass function. & 0.195 \\
\hline CTO & Water temperature $\left({ }^{\circ} \mathrm{C}\right)$ at which consumption is highest or optimum. & 13.7 \\
\hline CTM & Maximum water temperature $\left({ }^{\circ} \mathrm{C}\right)$ at which consumption can occurs. & 21.0 \\
\hline$C Q$ & Approximation of a $Q_{10}$ value over low water temperatures. & 2.41 \\
\hline \multicolumn{3}{|c|}{ Metabolism } \\
\hline$R_{A}$ & Intercept of the allometric mass function for respiration $\left(\mathrm{g} \mathrm{O}_{2} / \mathrm{g} / \mathrm{d}\right)$. & 0.008 \\
\hline$R_{B}$ & Slope of the allometric mass function for respiration. & 0.172 \\
\hline RTO & Water temperature at which respiration is highest or optimum. & 21 \\
\hline$R T M$ & Maximum water temperature $\left({ }^{\circ} \mathrm{C}\right)$ at which respiration can occurs. & 24 \\
\hline$R Q$ & Approximation of a $Q_{10}$ value over low water temperatures. & 1.88 \\
\hline$A C T$ & The Winberg activity multiplier. & 1.25 \\
\hline$S D A$ & $S D A$ Coefficient, specific dynamic action. & 0.17 \\
\hline \multicolumn{3}{|c|}{ Egestion and Excretion } \\
\hline$F$ & Proportion of consumed food egested. & 0.17 \\
\hline$U$ & Proportion of assimilated food excreted. & 0.09 \\
\hline
\end{tabular}

The temperature dependence function for consumption $\left(f_{c}(T)\right)$ used was:

$$
\begin{aligned}
f_{c}(T) & =V_{c}^{x_{c}} e^{\left(x_{c}-\left(1-V_{c}\right)\right)}, \\
\text { where } \quad V_{C} & =(C T M-T) /(C T M-C T O), \\
\text { and } \quad X_{C} & =0.137(C T M-C T O)^{2} /(C T M-C T O+2),
\end{aligned}
$$

where maximum water temperature that consumption will occur at is CTM, CTO is the optimal temperature for consumption, and $C Q$ is the slope of the relationship between consumption and temperature at relatively low temperatures.

Respiration $(R)$, the energy loss resulting from fish metabolism, was modeled using a species-specific function of predator weight, temperature and activity:

$$
R=R_{A} W^{R_{B}} A C T f_{R}(T),
$$

where $W$ is fish mass, $R_{A}$ and $R_{B}$ are the intercept and slope of the allometric mass function, respectively, $f R(T)$ is the temperature dependence function for respiration, $T$ is water temperature, and $A C T$ is the activity multiplier.

The temperature dependence function for respiration $f R(T)$ is:

$$
f_{R}(T)=V^{X_{R}} e^{\left(X_{R}-\left(1-V_{R}\right)\right)},
$$

where $V_{R}=(R T M-T) /(R T M-R T O)$, and $\quad X_{R}=0.137(R T M-R T O)^{2} /(R T M-R T O+2)$

where maximum temperature at which respiration occurs is at $R T M, R T O$ is the water temperature at which respiration is highest or optimum and $R Q$ is an approximation of the $Q_{10}$ (the rate at which $f R(T)$ increases at low water temperatures). An activity multiplier $(A C T)$ is incorporated in bioenergetics models to specify metabolic rates above standard metabolism that result from the activity of fish. The $A C T$ is a constant that is multiplied by the resting metabolism. An ACT multiplier of 1.25 was taken from Hansson et al. (1996).

The metabolic cost of digesting and assimilating ingested food is the energy expenditure for the post-absorptive processes that follows ingestion of food (Beamish and Trippel, 1990). The proportion of assimilated energy lost to $S D A(S)$ is defined as:

$$
S=S D A(C-F)
$$

where $S$ is the proportion of assimilated energy lost to specific dynamic action, $S D A$ is specific dynamic action, and $C$ is specific consumption rate in $\mathrm{g}$ prey/g body mass/day. The value of $S D A$ was modeled as a constant proportion of assimilated food, and used a value of $17 \%$ 
as the fixed proportion of the total consumption taken from Hansson et al. (1996).

Egestion and excretion components of energy budgets are commonly incorporated into bioenergetics models to express the loss of energy due to assimilated and non-assimilated waste products. These parameters are often modeled as a constant proportion of ingested energy. Waste losses by egestion (FA) and excretion (UA) were modeled as a constant proportion of energy consumed, which is the conventional approach, with egestion as:

$$
F=F A C
$$

and excretion as:

$$
U=U A(C-F),
$$

where $F$ is excretion, $U$ is egestion, and $C$ is consumption.

Gross conversion efficiency ( $G C E$ ) is a measure of the ability of an organism to convert ingested food into new tissue (Hansson et al., MS 1997) and is dependent on the quantity and quality of food available and the environmental conditions of the habitat (Hewett and Johnson, MS 1992; Hansson et al., MS 1997). The gross conversion efficiency $(G C E)$ was calculated as a percentage from:

$$
G C E=100 \Delta G / \Delta I
$$

where $\Delta G$ is the grams of growth in total weight gain around a defined period and $\Delta I$ is the grams of ingested prey eaten. The bioenergetics model computes losses due to spawning as a fixed proportion of weight on a specific day of the year (Hewett and Johnson, MS 1992). The proportional weight loss is the same for all the cohorts that are mature (different cohorts cannot have different spawning weight losses). According to Hansson et al. (1996) and McIntyre and Hutchings (2003), it was assumed that spawning losses were $12 \%$ of body weight for age-class 2 and older fish. Since it is known that the peak of spawning activity lies between late winter and early spring for Georges Bank and Gulf of Maine (Serchuk et al. 1994), spawning day was set at 15 February.

All parameters from Hansson et al. (1996) model (Table 1) were used for all Georges Bank and Gulf of Maine cod populations with the following assumptions: (1) there are no physiological differences in energy budget parameters in populations from Gulf of Maine and Georges Bank (e.g. consumption, respiration, egestion, defecation, physiological consumption) and (2) there are no differences in growth in gonadal tissue between Gulf of Maine and Georges Bank.
Mean bottom water temperatures data for Georges Bank and Gulf of Maine in 2004 were obtained from National Marine Fisheries Service (Personal Communication, D. Mountain National Marine Fisheries Service, Northeast Fisheries Science Center, Woodshole, MA). The model linearly interpolated temperature values between sampling dates (Fig. 1).

Proportional wet-weight diet composition data, obtained from age-classes 1-6 for Gulf of Maine, and ageclasses 1-9 for Georges Bank (Link and Garrison, 2002a) were used. Data from Link and Garrison (2002a) comes from the extensive food habits data set maintained by the National Marine Fisheries Services (NMFS) to characterize the diets of 59 fish and two squid species from 1973-1998 during annual bottom trawl surveys. These surveys were conducted each spring and autumn, and occasionally summer and winter, between Cape Fear, North Carolina and Nova Scotia. Given the lack of coverage of monthly sampling for each region from the NMFS trawl surveys (Link and Garrison, 2002a), assumptions were made that diet composition was constant across seasons in Gulf of Maine and Georges Bank. Diet composition data was regrouped as shown in Fig. 2. Once individual consumption had been estimated, numbers-at-age and estimates annual mortality for Georges Bank and Gulf of Maine cod were used to derive estimates of population consumption.

Estimates of initial numbers, annual mortality rates, and mean weight at age-classes 1-6 for Gulf of Maine, and age-class 1-9 for Georges Bank for year 2004 were taken from latest NMFS Stock assessment data (NEFSC, MS 2005). Age-class plus groups were not included in

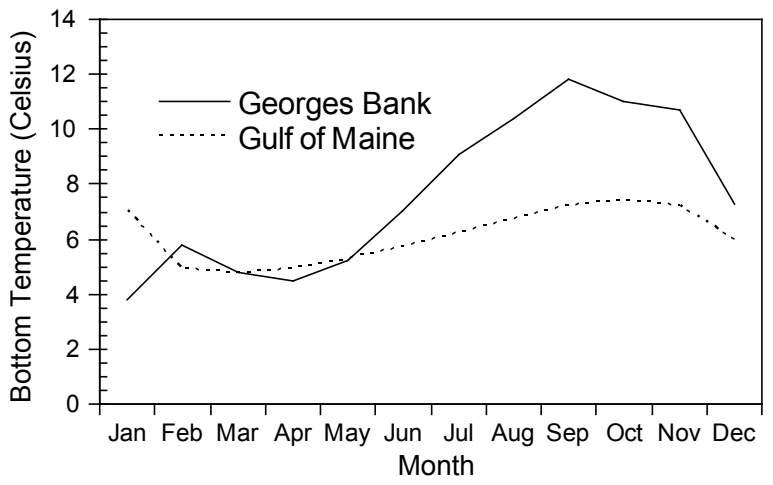

Fig. 1. Mean bottom temperatures $\left({ }^{\circ} \mathrm{C}\right)$ for Georges Bank and Gulf of Maine for year 2004. Data provided by National Marine Fisheries Service (Personal Communication, Dave Mountain National Marine Fisheries Service, Northeast Fisheries Science Center, Woodshole, MA). 


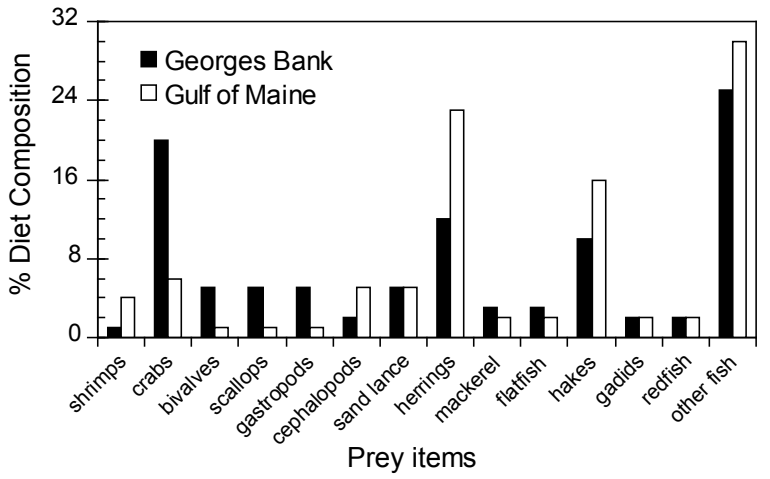

Fig. 2. Percent diet composition on Georges Bank and Gulf of Maine for the cod Gadus morhua, re-plotted from Link and Garrison (2002a).

the analyses since information of weight at age in this groups are clumped together masking potential growth rates among individuals.

Energy density values found in the literature were used for prey items that were most comparable to organisms found in Georges Bank and Gulf of Maine (Table 2). For predator energy density of cod, values were averaged using values from Lawson et al. (1998) and Hansson et al. (1996).

In most simulations, called "fit to end weight", the bioenergetics model was used to quantify prey consumption needed by juvenile and adult cod to achieve the estimated growth over a specified time interval. The bioenergetics software uses proportionality constant $(P)$ to model the proportion of maximum daily ration realized. An iteratively adjusted $P$ value allows the user-defined end weight to be precisely attained. Once the appropriate $P$ value has been determined, it is used for each day during the modeled period. Sensitivity analysis was performed on the model with data for growth, mortality, and seasonal temperature for Georges Bank for 2004. Previous studies have established that estimating consumption by fitting energetic models to observed growth is a robust procedure, relatively insensitive to uncertainties in the estimates of egestion, excretion, and SDA (Bartell et al., 1986). When the model is used in this manner, variability in estimates of consumption and wet weight between the endpoints of observed growth may be largely determined by the temperature dependence of respiration and consumption (Bartell et al., 1986). The sensitivity of the parameters that control the increasing portion of the Thornton and Lessem (1978) temperature dependence function $\left(C_{A}, C_{B}, C Q\right.$, and $\left.C T O\right)$, as it applies in the model to consumption, and the parameters of the respiration function $\left(R_{A}, R_{B}\right.$, and $\left.R Q\right)$ were analyzed
TABLE 2. Wet weight specific energy densities of Atlantic cod prey used in the model in this study.

\begin{tabular}{lcl}
\hline \hline Prey & Energy density $(\mathrm{J} / \mathrm{g})$ & Source \\
\hline Shrimps & 4800 & Lawson et al., 1998 \\
Crabs & 4800 & Thayer et al., 1973 \\
Bivalves & 2000 & Thayer et al., 1973 \\
Scallops & 5000 & Lawson et al., 1998 \\
Gastropods & 2619 & Davis et al., 1998 \\
Cephalopods & 5900 & Lawson et al., 1998 \\
Sand Lance & 4400 & Lawson et al., 1998 \\
Herrings & 9400 & Lawson et al., 1998 \\
Mackerel & 4000 & Lawson et al., 1998 \\
Flatfish & 4300 & Lawson et al., 1998 \\
Hakes & 4000 & Lawson et al., 1998 \\
Gadids & 4200 & Lawson et al., 1998 \\
Redfish & 5400 & Lawson et al., 1998 \\
Other fish & 5000 & Davis et al., 1998 \\
\hline
\end{tabular}

by adjusting parameters by $10 \%$ above and below their nominal values (Bartell et al., 1986). Errors are expressed as percentages of nominal values for total consumption (g) and gross conversion efficiency. The sensitivities of these parameters were analyzed separately for age-class 1 Georges Bank cod. This age-class was chosen for two reasons: (1) the temperature influence on consumption rates and metabolism on age-class $1 \mathrm{cod}$ is intermediate between those of age-class 0 fish and adults, (2) cod of this age should account for more biomass and production than most other ages in the Northeast Atlantic Continental Shelf.

\section{Statistical Analyses}

Estimates of population consumption were standardized by area $\left(\mathrm{kg} / \mathrm{km}^{2}\right)$ dividing total consumption within and all age-classes combined by total area of the region (Georges Bank $=45000 \mathrm{~km}^{2}$, Gulf of Maine $=91000 \mathrm{~km}^{2}$, Sherman et al., 1988). Differences in specific growth daily rates, specific consumption rates, and growth conversion efficiencies were tested using a non-parametric test (Mann Whitney on ranks) since the data failed Kolmogorov test of normality, and Levene Median test of homogeneous variances after squared root and log transformation.

\section{Results}

\section{Growth Performance}

Atlantic cod fed at $45-69 \%$ of their maximum consumption rate in all simulations (Table 3 ). Specific daily 
TABLE 3. Mean weight gain, individual cumulative consumption, spawning losses, and growth conversion efficiency (GCE) for average Georges Bank and Gulf of Maine cod ageclasses based on bioenergetics simulations. The $P$ value is the proportion of maximum consumption necessary to obtain simulated growth.

\begin{tabular}{cccccr}
\hline \hline Age-class & $P$ value & $\begin{array}{c}\text { Gametes } \\
(\mathrm{g})\end{array}$ & $\begin{array}{c}\text { Weight increment } \\
\text { gain }(\mathrm{kg})\end{array}$ & $\begin{array}{c}\text { Total individual } \\
\text { consumption }(\mathrm{kg})\end{array}$ & GCE \\
\hline Georges Bank & & & & & \\
1 & 0.686 & & 1.25 & 5.60 & 22.27 \\
2 & 0.531 & 264.48 & 0.636 & 7.02 & 9.07 \\
3 & 0.519 & 347.49 & 0.606 & 8.35 & 7.25 \\
4 & 0.536 & 431.33 & 0.898 & 10.4 & 8.63 \\
5 & 0.531 & 549.91 & 0.942 & 12.4 & 7.61 \\
6 & 0.524 & 673.03 & 0.913 & 14.2 & 6.44 \\
7 & 0.567 & 807.58 & 1.89 & 18.4 & 10.29 \\
8 & 0.538 & 1049.65 & 1.44 & 20.8 & 6.88 \\
9 & 0.584 & 1260.79 & 2.95 & 27.1 & 10.86 \\
\hline Gulf of Maine & & & & & \\
1 & 0.682 & & 1.135 & 3.63 & 31.25 \\
2 & 0.520 & 216.96 & 0.881 & 5.37 & 16.40 \\
3 & 0.499 & 335.03 & 1.171 & 7.74 & 15.12 \\
4 & 0.451 & 450.08 & 0.467 & 7.64 & 6.11 \\
5 & 0.522 & 531.69 & 1.587 & 10.8 & 14.73 \\
6 & 0.582 & 770.99 & 3.359 & 16.9 & 19.87 \\
\hline
\end{tabular}

growth rates were significantly higher in Georges Bank than in the Gulf of Maine (Mann Whitney Rank Sum Test $T=5390, p<0.001$, Fig. 3a). Similarly, specific daily consumption rates were significantly higher in Georges Bank than in the Gulf of Maine (Mann Whitney Rank Sum Test, $T=7940, p<0.03$, Fig. 3b). Much of the simulated growth and consumption of cod in Georges Bank occurred around the summer and autumn months when the ocean bottom temperatures ranged warmed from $7.5^{\circ} \mathrm{C}$ to $11^{\circ} \mathrm{C}$, whereas in Gulf of Maine growth and consumption was pretty much flat throughout all seasons (Figs. 3a-c). Simulated consumption rates for age-class 1 dropped from January through March, whereas the rates for age-classes 2-9 were relatively constant from June to November (Fig. 3b). Older ages became progressively more prone to weight loss during winter months (Fig. 3c).

Growth efficiencies for Atlantic cod were significantly higher in the Gulf of Maine than in Georges Bank (Mann Whitney Rank Sum Test, $T=9110, p<0.001$, Fig. 3d). Conversion efficiency showed a contrasting pattern unlike that of simulated growth and consumption rates: highest in the Gulf of Maine, lowest in Georges
Bank (Table 3). Gross conversion efficiency in the Gulf of Maine ranged from $31 \%$ at age-class 1 to $6.11 \%$ at age-class 4 (mean 17.2\%). The mean gross conversion efficiency (wet-weight basis) was $9.92 \%$ over all nine age-classes of cod in Georges Bank (Table 3); efficiency decreased from $22.1 \%$ at age-class 1 to $6.44 \%$ at ageclass 6. On Georges Bank and in the Gulf of Maine, growth efficiencies were almost constant throughout summer and autumn (Fig. 3d).

\section{Biomass and Gross Production}

In all regions, the population biomass was dominated by age-class 1 , and $85 \%$ or more of the biomass was in age-classes 0-5 (Table 4). Georges Bank had the highest production per area and Gulf of Maine the lowest. Production:biomass $(P: B)$ ratios, were almost similar in Georges Bank and Gulf of Maine (0.140-0.142). Finally, consumption:biomass $(C: B)$ ratios were slightly higher in Georges Bank (0.98) compared to Gulf of Maine (0.62). Although Georges Bank was estimated to have the highest biomass per area, relatively low simulated growth efficiencies seem to have depressed $P / B$ ratios. Production estimates across ages was highest for ageclass 1 in Georges Bank and Gulf of Maine, accounting 


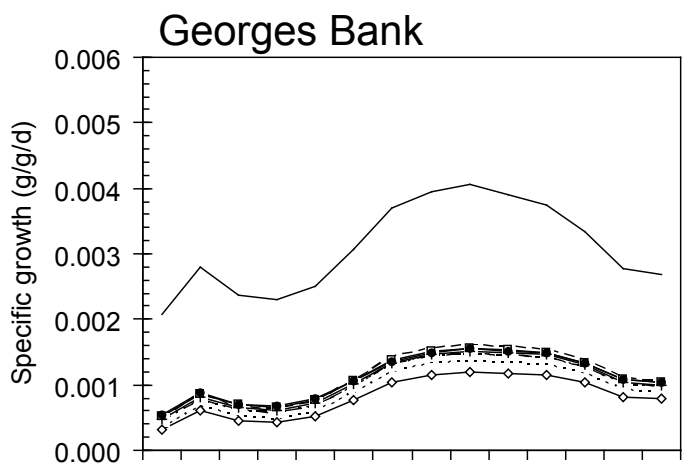

Gulf of Maine

A.
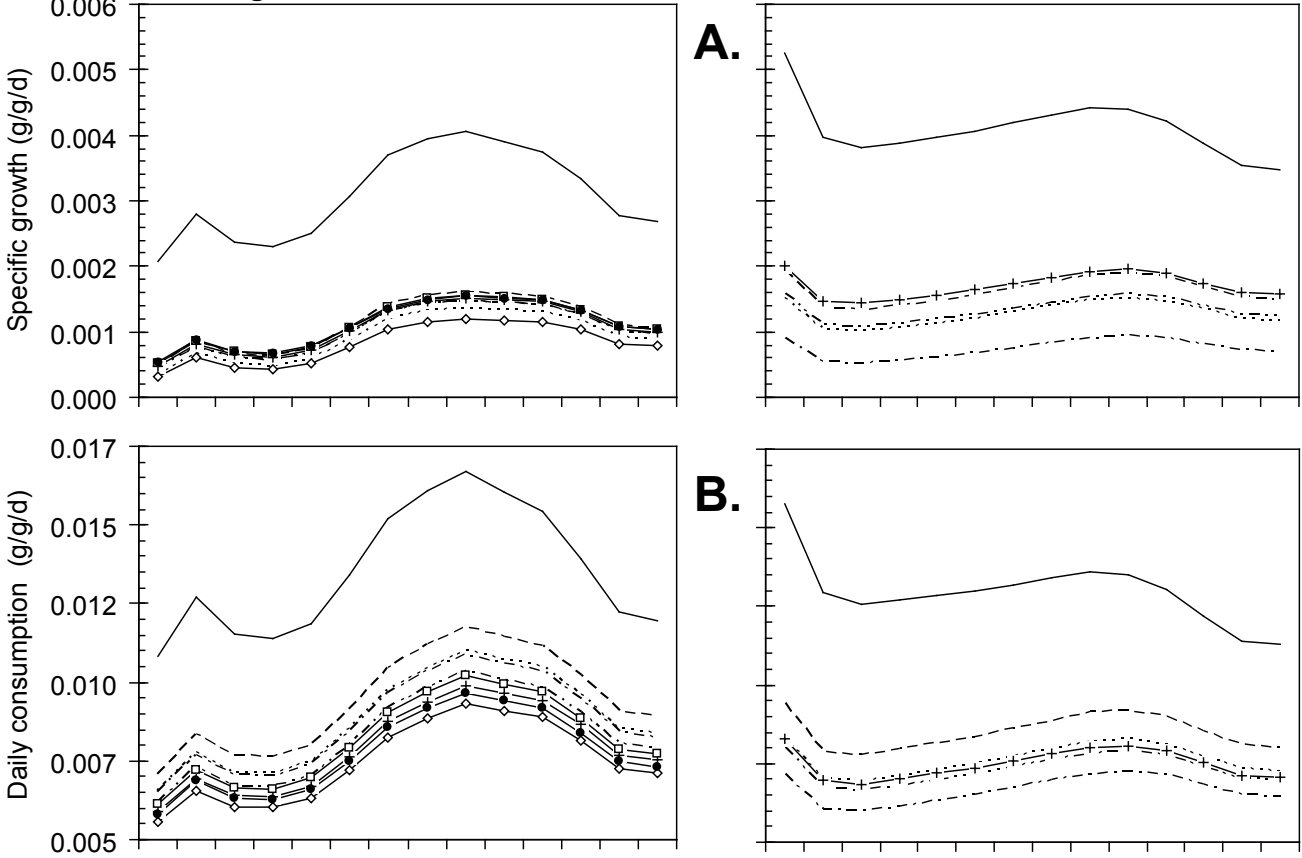

B.
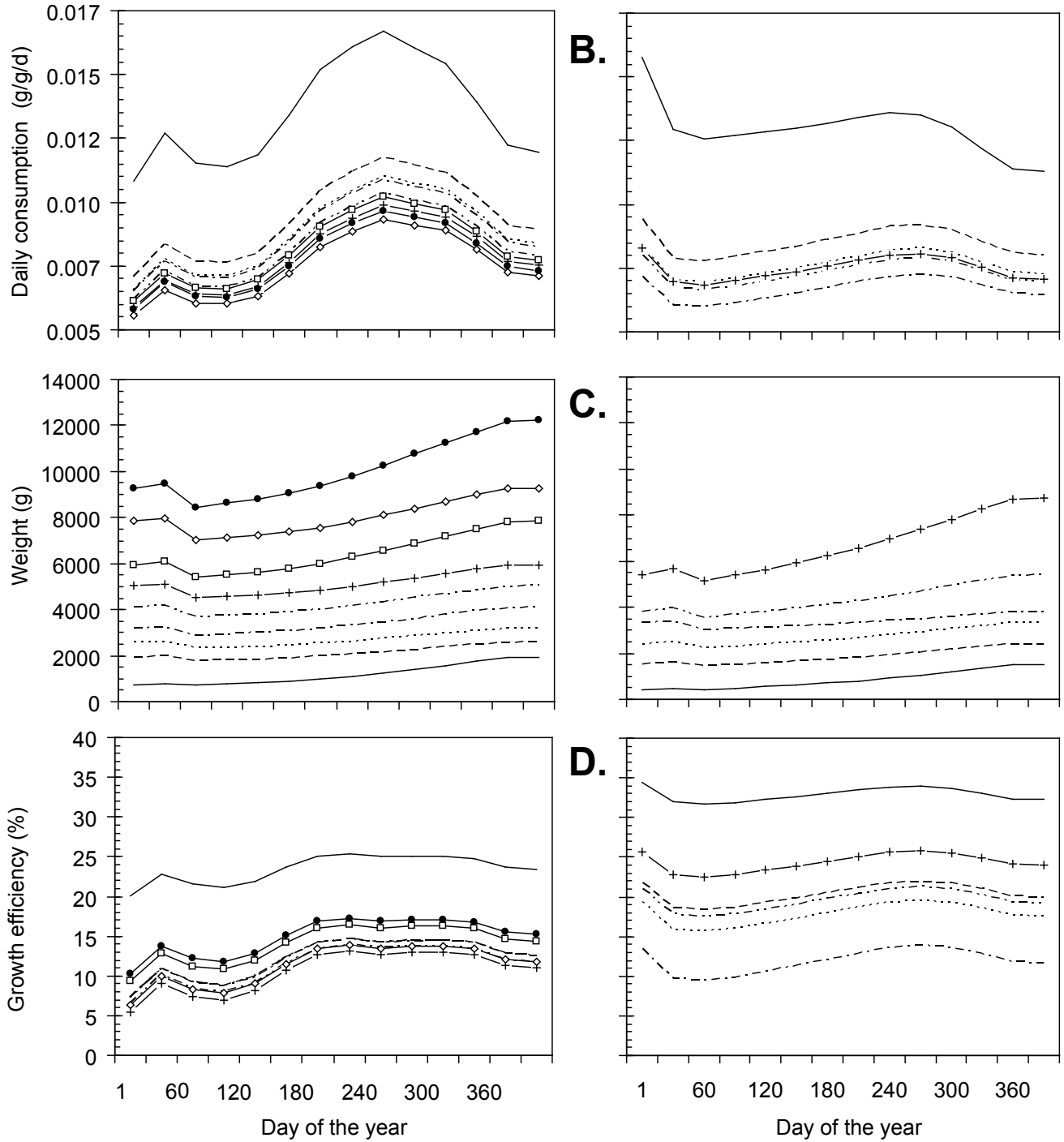

Age-class

$$
\longrightarrow 1---2 \cdots \cdots \cdot 3-\cdots-4-\cdots+\cdots 5-+-6 \multimap 7 \multimap-8 \multimap 9
$$

Fig. 3. Bioenergetic modeling simulations of the Atlantic cod by age class in 2004 on Georges Bank and Gulf of Maine: (A) specific daily rate $(\mathrm{g} / \mathrm{g} / \mathrm{d}),(\mathbf{B})$ simulated daily consumption rates $(\mathrm{g} / \mathrm{g} / \mathrm{d}),(\mathbf{C})$ weight increase (g), and (D) growth efficiency. 
TABLE 4. Simulation of consumption and production for populations of Atlantic cod of each age class by region. $\mathrm{PGCE}$ is population growth conversion efficiency, $\mathrm{P}: \mathrm{B}$ is the production:biomass ratios, $\mathrm{C}: \mathrm{B}$ is the consumption:biomass ratios and $t$ is metric tons.

\begin{tabular}{|c|c|c|c|c|c|c|c|}
\hline $\begin{array}{l}\text { Age- } \\
\text { class }\end{array}$ & $\begin{array}{l}\text { Total Annual } \\
\text { Consumption } \\
(\mathrm{t}) \\
\end{array}$ & $\begin{array}{c}\text { Annual Consumption } \\
\text { per Area } \\
\left(\mathrm{g} / \mathrm{m}^{2}\right) \\
\end{array}$ & $\begin{array}{l}\text { Total Annual Gross } \\
\text { Production } \\
(\mathrm{t})\end{array}$ & PGCE & $\begin{array}{l}\text { Monthly } \\
\text { Biomass } \\
(\text { mean, t) }\end{array}$ & $\mathrm{P}: \mathrm{B}$ & $\mathrm{C}: \mathrm{B}$ \\
\hline \multicolumn{8}{|c|}{ Georges Bank $\left(\right.$ area $\left.=45000 \mathrm{~km}^{2}\right)$} \\
\hline 1 & 3140 & 69.90 & 752 & 23.93 & 18100 & 0.04 & 0.17 \\
\hline 2 & 347 & 7.71 & 43 & 12.38 & 2970 & 0.01 & 0.12 \\
\hline 3 & 408 & 9.06 & 44 & 10.74 & 3810 & 0.01 & 0.11 \\
\hline 4 & 351 & 7.79 & 43 & 12.13 & 3310 & 0.01 & 0.11 \\
\hline 5 & 482 & 10.70 & 55 & 11.41 & 4800 & 0.01 & 0.10 \\
\hline 6 & 367 & 8.15 & 38 & 10.42 & 3870 & 0.01 & 0.09 \\
\hline 7 & 63 & 1.40 & 9 & 13.86 & 645 & 0.01 & 0.10 \\
\hline 8 & 94 & 2.08 & 11 & 11.21 & 1050 & 0.01 & 0.09 \\
\hline 9 & 35 & 0.77 & 5 & 14.88 & 370 & 0.01 & 0.09 \\
\hline \multicolumn{8}{|c|}{ Gulf of Maine (area $\left.=91000 \mathrm{~km}^{2}\right)$} \\
\hline 1 & 2150 & 23.60 & 710 & 33.05 & 13200 & 0.05 & 0.16 \\
\hline 2 & 372 & 4.09 & 76 & 20.43 & 3530 & 0.02 & 0.11 \\
\hline 3 & 924 & 10.20 & 165 & 17.90 & 9840 & 0.02 & 0.09 \\
\hline 4 & 48 & 0.53 & 6 & 11.63 & 593 & 0.01 & 0.08 \\
\hline 5 & 258 & 2.84 & 50 & 19.51 & 2880 & 0.02 & 0.09 \\
\hline 6 & 196 & 2.15 & 48 & 24.27 & 2120 & 0.02 & 0.09 \\
\hline
\end{tabular}

for approximately $60 \%$ of all gross production in these two regions (Table 4).

\section{Total Population Consumption}

Overall food consumption by cod on Georges Bank and in the Gulf of Maine in 2004 calculated in the model was $117 \mathrm{~kg} / \mathrm{km}^{2}$, and $43 \mathrm{~kg} / \mathrm{km}^{2}$, respectively. Annual fish consumption in Georges Bank was $73 \mathrm{~kg} / \mathrm{km}^{2}$, where 13 $\mathrm{kg} / \mathrm{km}^{2}$ of herring and $2 \mathrm{~kg} / \mathrm{km}^{2}$ of gadids were consumed (Fig. 4a, b). Percentage of fish on cod diets was about $63 \%$. Annual fish consumption in Gulf of Maine determined in the model was $35 \mathrm{~kg} / \mathrm{km}^{2}$, where $11 \mathrm{~kg} / \mathrm{km}^{2}$ of herring and $0.8 \mathrm{~kg} / \mathrm{km}^{2}$ of gadids were consumed (Fig. $4 c)$. Percentage of fish on cod diets was about $82 \%$.

\section{Sensitivity Analyses}

The sensitivities of the respiration and consumption parameters and their influences on consumption and growth efficiency were analyzed separately for age-class 1 Georges Bank cod (Table 5). Percentage error in all sensitivity analyses was less than $10 \%$ (Table 5); that is, a $10 \%$ parameter perturbation produced no more than an $8 \%$ error in the model output. Values for the consumption function were the least sensitive; all errors were less than $1 \%$. The temperature dependence $(R Q)$ of respiration was the most sensitive parameter, with errors between 5 and $8 \%$. Trends in sensitivity between ages were explored with the most sensitive parameter, the temperature dependence $(R Q)$ of respiration intercept relation (Table 6). Error size increased slightly with fish age. Error in all cases ranged from $5-11 \%$.

\section{Discussion}

Foraging conditions for the Atlantic cod are dynamic in US Northeast Continental Shelf, varying spatially. Overall growth performance, measured as growth efficiency, for Atlantic cod was lower on Georges Bank than in the Gulf of Maine. Monthly individual consumption demand for Atlantic cod was higher on Georges Bank than in the Gulf of Maine. This was primarily due to diet differences, driven by the higher proportions of energy rich prey in Georges Bank diets overall. Increasing water temperatures, which approached the upper limits of thermal tolerances for cod on Georges Bank, led to decreasing growth efficiencies for cod. Temperatures were less variable in the Gulf of Maine throughout all the months, which generated more consistent growth efficiencies. 

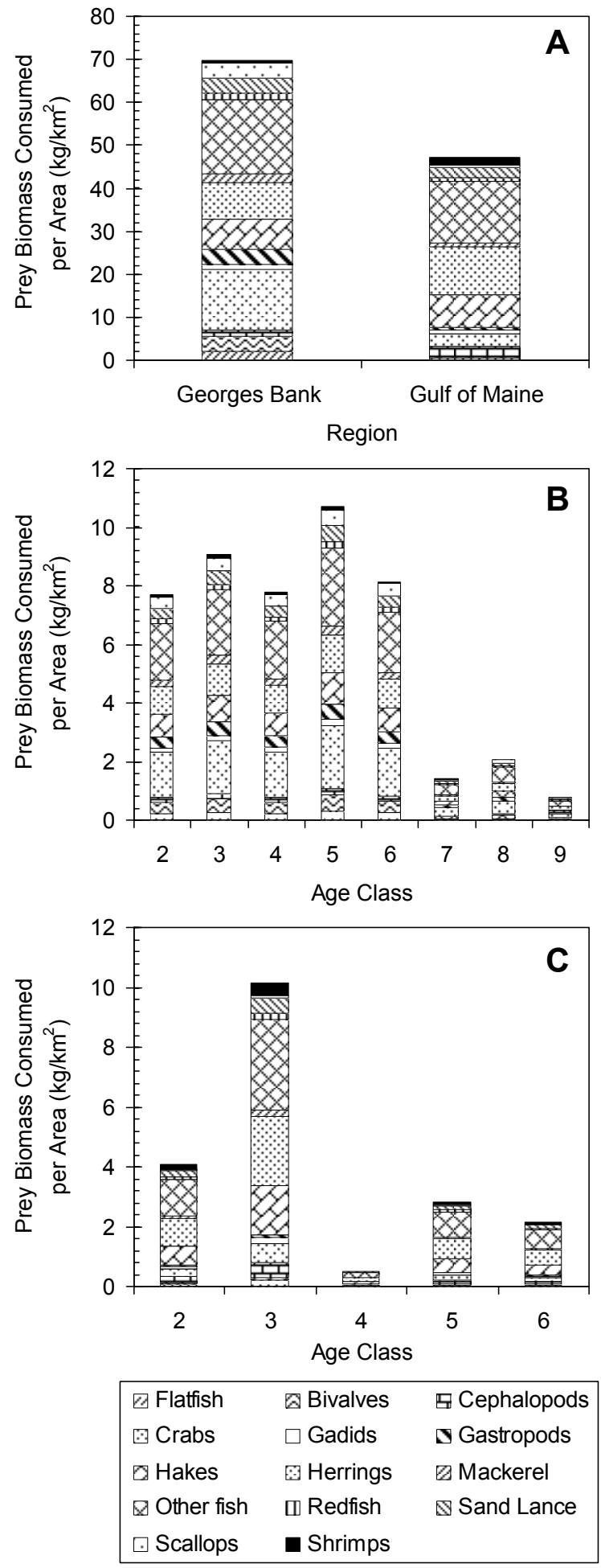

Fig. 4. Simulated total yearly consumption per area $\left(\mathrm{kg} / \mathrm{km}^{2}\right)$ of the Atlantic cod for (A) age-class 1 (B) Georges Bank, age-classes 2-9, and (C) Gulf of Maine, ageclasses 2-6.
Conversion efficiencies across ages for cod followed expected patterns, as other fish populations, and had reasonable magnitudes. The pattern of declining food conversion efficiency with age is a common ecological phenomenon (Diana, 1995). Metabolic and reproductive demands of older fish simply require a larger proportion of incoming energy relative to young fish. For Atlantic cod, predictions from the bioenergetics model for Gulf of Maine and Georges Bank in this study agree with the range of expected growth efficiencies for cod as reported by Hansson et al. (1996). They reported that growth efficiencies for North Sea cod ranged around $20-30 \%$ for age-class 1 fish and then gradually decreased.

The fact that Gulf of Maine cod populations had significantly higher growth efficiencies than in Georges Bank was not surprising. Peck et al. (2003) found in controlled feeding experiments that growth efficiency increased with decreasing temperature in gadids, and most markedly in cod. The trend of increasing growth efficiency with decreasing temperature has been previously observed by other researchers working on Atlantic cod age-class 0 juveniles (Brown et al., 1989) and larger juveniles (Hawkins et al., 1985), and seems to be an adaptive physiological characteristic of this predominantly cold-water species. However, factors other than temperature could explain some of the differences observed among cod populations. The generally higher food consumption and lower growth efficiency by cod populations from more southern populations might represent adaptations to regional conditions such as food availability. The cod from Gulf of Maine are found primarily within oligotrophic or mesotrophic systems, whereas the Georges Bank cod populations are in highly productive areas (Sherman et al., 1988). Conversion efficiencies are linked with prey density and quality (Stewart and Ibarra, 1991). With high prey availability, Georges Bank cod may be adapted to maximize foraging at the expense of efficiency. In contrast, cod from populations with less dense prey such as Gulf of Maine would have lower foraging rates and would have adapted to maintain high feeding efficiencies. In addition, temperature interacts with other environmental factors (e.g., oxygen concentration and habitat availability) which may also influence physiological adaptations (Schwalme and Chouinard, 1999).

The validity of estimates derived from bioenergetics modeling depends on the accuracy of its inputs. Any errors in these inputs will propagate throughout the model, and consequently, consumption estimates risk losing 
TABLE 5. Sensitivity analyses of estimated annual total consumption (C, summed over all stimulate days for age-class 1 , nominal value $=5593.80 \mathrm{~g}$ ) and average daily gross conversion efficiency $(\mathrm{GCE}$, nominal value $=23.5)$ from the Georges Bank cod model using two values for each of the respiration and consumption parameters that varied by plus and minus $10 \%$ of the nominal value given in Table 1 .

\begin{tabular}{|c|c|c|c|c|c|}
\hline \multicolumn{2}{|c|}{ Parameter } & \multirow[b]{2}{*}{$\mathrm{C}$} & \multirow[b]{2}{*}{ GCE } & \multicolumn{2}{|c|}{ Percentage Error in } \\
\hline Symbol & Value used & & & $\mathrm{C}$ & GCE \\
\hline \multicolumn{6}{|l|}{ Respiration } \\
\hline$R_{A}$ & $\begin{array}{l}0.0088 \\
0.0072\end{array}$ & $\begin{array}{l}5919.93 \\
5258.08\end{array}$ & $\begin{array}{l}22.1 \\
25.0\end{array}$ & $\begin{array}{r}5.830 \\
-6.002\end{array}$ & $\begin{array}{r}-5.957 \\
6.383\end{array}$ \\
\hline$R_{B}$ & $\begin{array}{l}0.1892 \\
0.1548\end{array}$ & $\begin{array}{ll}5 & 207.29 \\
6 & 029.13\end{array}$ & $\begin{array}{l}25.2 \\
21.7\end{array}$ & $\begin{array}{r}-6.910 \\
7.782\end{array}$ & $\begin{array}{r}7.234 \\
-7.660\end{array}$ \\
\hline$R_{Q}$ & $\begin{array}{l}2.0680 \\
1.6920\end{array}$ & $\begin{array}{l}5312.23 \\
5907.98\end{array}$ & $\begin{array}{l}25.2 \\
21.6\end{array}$ & $\begin{array}{r}-5.034 \\
5.617\end{array}$ & $\begin{array}{r}7.234 \\
-8.085\end{array}$ \\
\hline \multicolumn{6}{|l|}{ Consumption } \\
\hline$C_{A}$ & $\begin{array}{l}0.1090 \\
0.0890\end{array}$ & $\begin{array}{l}5590.21 \\
5593.80\end{array}$ & $\begin{array}{l}23.4 \\
23.4\end{array}$ & $\begin{array}{r}-0.064 \\
0.000\end{array}$ & $\begin{array}{l}-0.426 \\
-0.426\end{array}$ \\
\hline$C_{B}$ & $\begin{array}{l}0.2140 \\
0.1750\end{array}$ & $\begin{array}{l}5606.68 \\
5577.81\end{array}$ & $\begin{array}{l}23.4 \\
23.4\end{array}$ & $\begin{array}{r}0.230 \\
-0.286\end{array}$ & $\begin{array}{l}-0.426 \\
-0.426\end{array}$ \\
\hline$C Q$ & $\begin{array}{l}2.6500 \\
2.1700\end{array}$ & $\begin{array}{l}5545.09 \\
5638.62\end{array}$ & $\begin{array}{l}23.1 \\
23.8\end{array}$ & $\begin{array}{r}-0.871 \\
0.801\end{array}$ & $\begin{array}{r}-1.702 \\
1.277\end{array}$ \\
\hline CTO & $\begin{array}{l}15.7000 \\
12.3300\end{array}$ & $\begin{array}{l}5563.00 \\
5643.52\end{array}$ & $\begin{array}{l}23.2 \\
23.8\end{array}$ & $\begin{array}{r}-0.551 \\
0.889\end{array}$ & $\begin{array}{r}-1.277 \\
1.277\end{array}$ \\
\hline \multicolumn{6}{|c|}{ Energy Density (J/g) } \\
\hline $\begin{array}{l}\text { Predator } \\
\text { Energy Density }\end{array}$ & $\begin{array}{l}5500.00 \\
4500.00 \\
\end{array}$ & $\begin{array}{l}5822.00 \\
5363.56 \\
\end{array}$ & $\begin{array}{l}22.6 \\
24.6 \\
\end{array}$ & $\begin{array}{r}4.080 \\
-4.116 \\
\end{array}$ & $\begin{array}{r}-3.830 \\
4.681 \\
\end{array}$ \\
\hline
\end{tabular}

accuracy (Ney, 1993). Nevertheless, in this study, the estimates of daily rations for cod for Georges Bank (0.7$1.3 \%$ body weight) were in good agreement with previous studies from Tsou and Collie (2001) $(0.5-1.4 \%$ body weight), Durbin et al. (1983) (0.9-1.5\% body weight), and Grosslein et al. (1980) (0.5-1.1\% body weight). Thus, the consumption rates from this study seem reasonable for further analyses.

Population consumption by cod is dominated by young fishes. Many researchers (Stewart and Ibarra, 1991; Ney, 1993) reported a similar demographic pattern for piscivorous fish populations. Consumption increases with increase in age on an individual basis, but this increase cannot counteract effects of the rapid decline in numbers-at-age, which leads to decreases in cohort consumption for older ages.

Seasonal consumption by cod varied considerably despite the modeling of constant weight gain through- out the growth season. Consumption during the summer far exceeded that of any other season. Elevated water temperatures in July through November meant much larger respiration costs at this time of year. Much more food would have to be ingested than during cooler periods in order to attain a given weight increase during these months. It could be possible that weight gain for cod during the growth season is not linear but rather occurs primarily in summer and autumn, with simple weight maintenance during the coldest months. Simulations indicated that even if weight were only maintained, however, consumption by the cod populations during the summer would still be slightly higher than consumption during spring and autumn. There is little doubt that estimates of winter consumption by both Georges Banks and Gulf of Maine cod are most speculative. It was assumed that weight loss would occur during the coldest months. Schwalme and Chouinard (1999) found that cod from Gulf of St. Lawrence fed very little during the five winter months (December to April), and lost $25-27 \%$ of 
TABLE 6. Sensitivity analyses of estimated individual annual consumption and total growh conversion efficientcy (CGE) by age-class from the Georges Bank cod model. The temperature dependence coefficient $(R Q)$ was varied by plus and minus $10 \%$ about its nominal value.

\begin{tabular}{|c|c|c|c|c|}
\hline \multirow[b]{2}{*}{ Age -class } & \multirow{2}{*}{$\begin{array}{c}\text { Consumption } \\
(\mathrm{g})\end{array}$} & \multirow[b]{2}{*}{ Total GCE } & \multicolumn{2}{|c|}{ Percentage Error in } \\
\hline & & & Consumption & GCE \\
\hline \multicolumn{5}{|c|}{$R Q=1.88$ (nominal) } \\
\hline 1 & 5593.80 & 24 & & \\
\hline 2 & 7006.66 & 13 & & \\
\hline 3 & 8335.94 & 11 & & \\
\hline 4 & 10378.20 & 12 & & \\
\hline 5 & 12347.88 & 12 & & \\
\hline 6 & 14144.98 & 11 & & \\
\hline 7 & 18350.94 & 14 & & \\
\hline 8 & 20796.25 & 11 & & \\
\hline 9 & 27064.43 & 15 & & \\
\hline \multicolumn{5}{|c|}{$R Q=2.068($ nominal $+10 \%)$} \\
\hline 1 & 5312.23 & 25 & -5.034 & 5.729 \\
\hline 2 & 6528.92 & 14 & -6.818 & 8.945 \\
\hline 3 & 7739.77 & 12 & -7.152 & 10.350 \\
\hline 4 & 9662.73 & 14 & -6.894 & 9.909 \\
\hline 5 & 11469.62 & 13 & -7.113 & 10.058 \\
\hline 6 & 13145.63 & 12 & -7.065 & 11.509 \\
\hline 7 & 17135.23 & 16 & -6.625 & 10.138 \\
\hline 8 & 19278.93 & 13 & -7.296 & 10.315 \\
\hline 9 & 25255.83 & 16 & -6.683 & 8.989 \\
\hline \multicolumn{5}{|c|}{$R Q=1.692($ nominal $-10 \%)$} \\
\hline 1 & 5907.98 & 23 & 5.617 & -5.868 \\
\hline 2 & 7553.22 & 11 & 7.800 & -8.725 \\
\hline 3 & 9002.66 & 10 & 7.998 & -10.620 \\
\hline 4 & 11195.31 & 11 & 7.873 & -9.836 \\
\hline 5 & 11469.62 & 13 & -7.113 & 10.058 \\
\hline 6 & 15309.25 & 10 & 8.231 & -11.040 \\
\hline 7 & 17135.23 & 16 & -6.625 & 10.138 \\
\hline 8 & 22458.99 & 10 & 7.995 & -11.150 \\
\hline
\end{tabular}

their carcass weight and $76-84 \%$ of their liver dry weight during this time. Lack of information on cod diets during winter adds to the uncertainty of consumption estimates during this season. Bioenergetic simulations have been shown to be most imprecise in winter (tending to overestimate consumption) due to bias in physiological parameters at cold temperatures (Hartman and Brandt, 1995). Estimates of winter consumption in this study should be viewed as lower limits to consumption of these species in this season.

Estimates of total consumption in Georges Bank from this study $\left(117 \mathrm{~kg} / \mathrm{km}^{2}\right.$ overall total consumption estimate, and $73 \mathrm{~kg} / \mathrm{km}^{2}$ fish consumption estimate) for age-classses 1-9 combined, were in agreement with Link and Garrison (2002b) estimates of total consumption and 
fish consumption for 1992-1998. Their results for annual total consumption ranged from $89-200 \mathrm{~kg} / \mathrm{km}^{2}$, with an average of $145 \mathrm{~kg} / \mathrm{km}^{2}$, whereas annual fish consumption ranged from $44-133 \mathrm{~kg} / \mathrm{km}^{2}$, with an average of $88 \mathrm{~kg} /$ $\mathrm{km}^{2}$. As for Gulf of Maine, no recent estimates of consumption were available from the literature, so comparisons with this study were precluded. The region-specific modeling simulations indicated that much of the production by Atlantic cod in the Gulf of Maine comes from growth of fish in age-classes 1-3, and in Georges Bank by age-classes $1-5$. It is possible that a strong year class such as 2004 was a factor driving the results of production, biomass, and consumption. The size of the first year class in 2004 for Gulf of Maine was the second strongest year-class identified in time series data from 1982-2004 for Gulf of Maine (NMFS, MS 2005). In Georges Bank the 2004 first year class was the sixth strongest year class from time series data from 1978-2004 (NEFSC, 2005). Thus, it may be likely that this year class size is influencing the results by overestimation of population estimates of biomass, consumption, and production.

The values from simulations in this study reflect potential, not necessarily precise quantitative estimates of consumption in the field, and therefore they should not be used to make quantitative predictions of impact on specific prey populations. However, they are useful for making general estimates and relative comparisons of fish consumption rate and growth efficiency (Bartell et al., 1986; Ney, 1993). In this study, simulations suggest that Atlantic cod occupying the Georges Bank sampling region may experience relatively high growth and consumption rates, due to the availability of high quality prey resources and warmer temperatures. However, growth conditions appear to be variable, as diet quality and water temperatures fluctuate on a monthly scale. Therefore, the timing of juvenile and adult cod encountering high quality prey resources may greatly affect their potential for growth. Juvenile and adult cod occupying the Gulf of Maine sampling region, on the other hand, may experience more moderate growth rates, since a greater consistency of foraging conditions and water temperatures may translate to a more constant potential for growth (growth efficiency). Therefore, the seasonal migration timing may not be as important for the growth performance of Atlantic cod. Timing, however, may affect other critical factors, including the vulnerability of these juveniles to potential predators.

This study compared relatively areas from the US Northeast Continental Shelf and results cannot be extrapolated to make broad regional generalizations. Fu- ture efforts are needed to synthesize results from current and ongoing studies in order to expand the spatial coverage and facilitate a more comprehensive understanding of the ecology of cod in US Northeast Continental Shelf. Comparisons between different areas in US Northeast Continental Shelf may help to determine whether the Atlantic cod face spatial and temporal differences in the forage base and environmental conditions that could affect their early marine growth potential.

\section{Acknowledgements}

This paper benefited from the comments and suggestions from Michael J. Fogarty, William Overholtz, James Kitchell, Sture Hansson, Dave Bengtson, Jeremy Collie, Larry Buckley, Jon Hare, and Nancie Cummings. The author wants to thank Dave Mountain, Maureen Taylor, and Jason Link for providing temperature and cod diet data.

\section{References}

BARTELL, S. M., J. E. BRECK, R. H. GARDNER, and A. L. BRENKERT. 1986. Individual parameter perturbation and error analysis of fish bioenergetics models. Can. J. Fish. Aquat. Sci., 43: 160-168.

BEAMISH, F. W. H., and E. A. TRIPPEL. 1990. Heat increment: a static or dynamic dimension in bioenergetic models. Trans. Am. Fish. Soc., 119: 649-661. doi:10.1577/15488659(1990) $119<0649:$ HIASOD $>2.3 . \mathrm{CO} ; 2$

BRANDT, S. B., and K. J. HARTMAN. 1993. Innovative approaches with bioenergetics models: future applications to fish ecology and management. Trans. Amer. Fish. Soc., 122: 731-735. doi:10.1577/1548-8659(1993)122<0731: $\mathrm{IAWBMF}>2.3 . \mathrm{CO} ; 2$

BROWN, J. A., P. PEPIN, D. A. METHVEN, and D. C. SOMERTON. 1989. The feeding, growth and behavior of juvenile cod in cold marine environments: a field and laboratory study. J. Fish Bio., 35: 373-380. doi:10.1111/ j.1095-8649.1989.tb02989.x

CHOI, J. S., K. T. FRANK, W. C. LEGGETT, and K. DRINKWATER. 2004. Transition to an alternate state in a continental shelf ecosystem. Can. J. Fish. Aquat. Sci., 61: 505-510. doi:10.1139/f04-079

DAVIS, N. D., K. W. MYERS, and Y. ISHIDA. 1998. Caloric value of high-seas salmon prey organisms and simulated salmon ocean growth and prey consumption. N. Pac. Andr. Fish. Comm. Bull., 1: 146-152.

DIANA, J. S. 1995. Biology and ecology of fishes. Cooper Publishing, Carmel, Indiana. $441 \mathrm{p}$.

DURBIN, E. G., A. G. DURBIN, R. W. LANGTON, and R. E. BOWMAN. 1983. Stomach contents of silver hake, Merluccius bilinearis, and Atlantic cod, Gadus morhua, and estimation of their daily rations. Fish. Bull. U.S., 81: 437-454. 
FRANK, K., B. PETRIE, J. CHOI, and W. LEGGETT. 2005. Trophic cascades in a formerly cod-dominated ecosystem. Science, 308: 1621-23. doi:10.1126/science. 1113075

GROSSLEIN, M. D., R. W. LANGTON, and M. P. SISSENWINE. 1980. Recent fluctuations in pelagic fish stocks of the northwest Atlantic, Georges Bank region, in relation to species interactions. Rapp. P.-V. Reun. Cons. Int. Explor. Mer., 177: 374-404.

HANSEN, M. J., D. BOISCLAIR, S. B. BRANDT, and S. W. HEWETT. 1993. Applications of bioenergetics models to fish ecology and management: Where do we go from here? Trans. Amer. Fish. Soc., 122: 1019-1030. doi:10.1577/1548-8659(1993)122<1019:AOBMTF $>2.3$. $\mathrm{CO} ; 2$

HANSON, P. C., T. B. JOHNSON, D. E. SCHINDLER, and J. F. KITCHELL. MS 1997. Fish bioenergetics 3.0 software for Windows ${ }^{\circledR}$. WISCU-T-97-001. University of Wisconsin Sea Grant Institue, Madison, WI. 116 p.

HANSSON, S., L. G. RUDSTAM, J. F. KITCHELL, M. HILDEN, B. L. JOHNSON, and P. E. PEPPARD. 1996. Predation rates by North Sea cod (Gadus morhua) - predictions from models on gastric evacuation and bioenergetics. ICES. J. Mar. Sci., 53: 107-114. doi:10.1006/ jmsc. 1996.0010

HARTMAN, K. J, and S. B. BRANDT. 1995. Comparative energetics and the development of bioenergetics models for sympatric estuarine piscivores. Can. J. Fish. Aquat. Sci., 52: $1647-1666$.

HEWETT, S. W. 1989. Ecological applications of bioenergetics models. Amer. Fish. Soc. Symp., 6: 113-120.

HEWETT, S. W., and B. L. JOHNSON. MS 1992. Fish bioenergetics model 2: and update of a generalized bioenergetics model of fish growth for microcomputers. University of Wiscsconsin Sea Grant Tech. Rep. WIS-SG-92-250, University of Wisconsin Sea Grant Institute, Madison, WI. 79 p.

HAWKINS, A. D., N. M. SOOFIANI, and G. W. SMITH. 1985. Growth and feeding of juvenile cod (Gadus morhua L.). J. Cons. Int. Explor. Mer., 42: 11-32.

LAWSON, J. W., A. M. MAGALHÃES, and E. H. MILLER. 1998. Important prey species of marinevertebrate predators in the northwest Atlantic: proximate composition and energy density. Mar. Ecol. Prog. Ser., 164: 13-20.

LINK, J. S., and L. P. GARRISON. 2002a. Trophic ecology of Atlantic cod Gadus morhua on the northeast US continental shelf. Mar. Ecol. Prog. Ser., 227: 109-123.

$2002 b$. Changes in piscivory associated with exploitation of the finfish community on Georges Bank. Fish Res., 55: 71-86. doi:10.1016/S0165-7836(01)00300-9

MCINTYRE, T. M., and J. A. HUTCHINGS. 2003. Smallscale temporal and spatial variation in Atlantic cod ( $\mathrm{Ga}$ dus morhua) life history. Can. J. Fish. Aquat. Sci., 60: 1111-1121. doi:10.1139/f03-090

NEY, J. J. 1993. Bioenergetics modeling today: Growing pains on the cutting edge. Trans. Amer. Fish. Soc., 122: 736-748. doi:10.1577/1548-8659(1993)122<0736:BMTGPO $>2.3$. $\mathrm{CO} ; 2$

NEFSC. MS 2005. Assessment of 19 Northeast groundfish stocks through 2004. 2005. Groundfish Assessment Review Meeting (2005 GARM), Northeast Fisheries Science Center, Woods Hole, Massachusetts, 15-19 August 2005.

PALSSON, O. K. 1994. A review of the trophic interactions of cod stocks in the North Atlantic. ICES. Mar. Sci. Symp., 198: $553-575$.

PECK, M. A., L. J. BUCKLEY, E. M. CALDARONE, and D. A. BENGTSON. 2003. Effects of food consumption and temperature on growth rate and biochemical-based indicators of growth in early juvenile Atlantic cod (Gadus morhua) and haddock (Melanogrammus aeglefinus). Mar. Ecol. Prog. Ser., 251: 233-243.

ROSE, G. A., and W. C. LEGGETT. 1989. Interactive effects of geophysically-forced sea temperatures and prey abundance on mesoscale coastal distributions of a marine predator, Atlantic cod (Gadus morhua). Can. J. Fish. Aquat. Sci., 46: 1904-1913.

SERCHUK, F. M., M. D. GROSSLEIN, R. G. LOUGH, D. G. MOUNTAIN, and L. O'BRIEN. 1994. Fishery and environmental factors affecting trends and fluctuations in the Georges Bank and Gulf of Maine Atlantic cod stocks: An overview. ICES. Mar. Sci. Symp., 198: 77-109.

SHERMAN, K., M. GROSSLEIN, D. MOUNTAIN, D. BUSCH, J. O'REILLY, and R. THEROUX. 1988. The Continental Shelf ecosystem off the Northeast coast of the United States. In: H. Postma and J.J. Zijlstra (eds.). Ecosystems of the World 27: Continental Shelves. Elsevier, Amsterdam, The Netherlands, pp. 279-337.

SCHWALME, K., and G. A. CHOUINARD. 1999. Seasonal dynamics in feeding, organ weights, and reproductive maturation of Atlantic cod (Gadus morhua) in the southern Gulf of St. Lawrence. ICES J. Mar. Sci., 56: 303-319. doi:10.1006/jmsc.1999.0458

STEWART, D. J., and M. IBARRA. 1991. Predation and production by salmonine fishes in Lake Michigan, 1978-88. Can. J. Fish. Aquat. Sci., 48: 909-922.

THAYER, G. W., W. E. SCHAAF, J. W. ANGELOVIC, and M. W. LACROIX. 1973. Caloric measurements of some estuarine organisms. Fish. Bull., 71: 289-296.

THORNTON, K. W., and A. S. LESSEM. 1978. A temperature algorithm for modifying biological rates. Trans. Amer. Fish. Soc., 107: 284-287. doi:10.1577/15488659(1978) $107<284$ :ATAFMB $>2.0$. CO 2

TSOU, T. S., and J. S. COLLIE. 2001. Estimating predation mortality in the Georges Bank fish community. Can. J. Fish. Aquat. Sci., 58: 908-922. doi:10.1139/cjfas-58-5908

WORM B., and R. A. MYERS. 2003. Meta-analysis of codshrimp interactions reveals top-down control in oceanic food webs. Ecology., 84: 162-173. 